\title{
Paraplegia
}

\section{Changes in Ambulation Parameters in Spinal Cord Injury Individuals Following Rehabilitation}

\author{
J. S. Yakura, MS, PT, R. L. Waters, MD, R. H. Adkins, PhD \\ Rancho Los Amigos Medical Center, Downey, California, USA.
}

\section{Summary}

The energy cost and gait parameters of 10 spinal cord injury patients (mean age $=21 \cdot 7 \pm 2 \cdot 3$ years) were measured at discharge from initial rehabilitation and at 1 year follow-up. At follow-up testing patients walked faster $(59.5 \mathrm{~m} / \mathrm{minute}$ vs $40.4 \mathrm{~m} /$ minutes; $p<0.001)$, more efficiently $(0.26 \mathrm{ml} \mathrm{O} / \mathrm{kg} \cdot \mathrm{m}$ vs $0.40 \mathrm{ml} \mathrm{O} / \mathrm{kg} \cdot \mathrm{m}$; $p<0.05)$ had slower heart rates (115 beats/minute vs 133 beats/minute; $p<0.01)$, and required decreased axial load on upper extremity assistive devices (18\% body weight vs $26 \%$ body weight; $p<0.03$ ).

At follow-up testing, those patients with remaining weakness in the lower limbs had greater conditioning effects (increased rate of oxygen consumption and oxygen pulse) than those patients with relatively stronger limbs. These findings indicate that clinicians can expect significant improvements in functional ambulation performance in the first year following initial rehabilitation due to improved strength and conditioning.

Key words: Spinal cord injuries; Gait; Oxygen consumption; Rehabilitation.

The majority of energy cost studies involving spinal cord injured (SCI) individuals have been performed on newly injured inpatients or chronic injuries in which repeat testing was not performed (Chantraine, 1984; Clinkingbeard, 1964; Gordon, 1956; Huang, 1979; Merkel, 1985; Waters, 1985; Waters, 1989). Clinkingbeard retested $11 \mathrm{SCI}$ ambulators to assess longitudinal changes during rehabilitation, however, repeat testing of SCI ambulators has not been done on patients following discharge more than 1 year post-injury (Clinkingbeard, 1964). Yet, in clinical practice, many patients continue to gain strength after rehabilitation, increase their capacity to exercise, and improve overall gait performance. The purpose of this study was to quantify changes in physiological and gait performance parameters of SCI ambulators which may occur following discharge from initial rehabilitation. 


\section{Materials and methods}

Parameters of energy expenditure and gait performance of $10 \mathrm{SCI}$ ambulators (10 males) were measured at discharge from initial rehabilitation and at approximately 1 year follow-up. At initial testing the average age was $27 \cdot 1$ years $( \pm 2.3$ years), average weight $72.1 \mathrm{~kg}( \pm 8.4 \mathrm{~kg})$, and mean height $1.8 \mathrm{~m}( \pm 0.05 \mathrm{~m})$. The average interval between date of injury and initial testing was 122 days $( \pm 73$ days). The mean time between date of injury and the follow-up test was 455 days ( \pm 92 days).

Three of the 10 patients had incomplete quadriplegia, and of the remaining 7 paraplegic patients, 5 had incomplete injuries and 2 had complete lesions (Table

Table I Spinal cord injury ambulators

\begin{tabular}{rccccc}
\hline Case & $\begin{array}{c}\text { Age } \\
(\text { yrs })\end{array}$ & $\begin{array}{c}\text { Weight } \\
(\mathrm{lbs})\end{array}$ & $\begin{array}{c}\text { Height } \\
(\mathrm{m})\end{array}$ & Injury level & $\begin{array}{c}\text { AMI GRP } \\
\text { (initial/follow-up) }\end{array}$ \\
\cline { 6 - 7 } 1 & 21 & 132 & $1 \cdot 77$ & L2 incomplete & $2 / 3$ \\
2 & 21 & 169 & $1 \cdot 83$ & C3 incomplete & $3 / 3$ \\
3 & 20 & 141 & $1 \cdot 83$ & T10 incomplete & $3 / 3$ \\
4 & 22 & 177 & $1 \cdot 77$ & C3 incomplete & $3 / 3$ \\
5 & 24 & 188 & $1 \cdot 83$ & T12 incomplete & $2 / 2$ \\
6 & 20 & 147 & $1 \cdot 72$ & L3 incomplete & $2 / 3$ \\
7 & 27 & 150 & $1 \cdot 70$ & C5 incomplete & $3 / 3$ \\
8 & 20 & 172 & $1 \cdot 83$ & T4 incomplete & $1 / 2$ \\
9 & 22 & 145 & $1 \cdot 75$ & L3 complete & $2 / 2$ \\
10 & 19 & 165 & $1 \cdot 85$ & T12 complete & $1 / 1$ \\
\hline
\end{tabular}

I). At the initial testing all patients required lower extremity orthoses: 6 patients required bilateral ankle-foot orthoses (AFO); 3 required at least one knee to be stabilised with a knee-ankle-foot orthosis (KAFO) with or without contralateral AFO; and 1 walked with bilateral KAFOs utilising a swing-through gait.

All patients completed a rehabilitation programme including ambulation training, and were able to ambulate without assistance for at least 5 minutes at initial testing. Each patient's trunk strength was adequate to enable independent sitting.

\section{Testing procedure}

Procedures for energy expenditure testing have been previously described (Waters, $1978,1985)$. Depending on the length of time the subject was able to walk, expired air was collected during the fourth, fifth, tenth, fifteenth, and twentieth minutes using a modified Douglas bag collection technique described in previous reports (Waters, 1988). Because the number of measurement points available were different for different subjects, i.e. some were able to walk for less than 10 minutes, some for between 10 and 15 minutes, some for between 15 and 20 minutes, and some for longer than 20 minutes, physiological and mechnical gait measures were averaged across available testing samples for each subject.

Preceding outdoor energy expenditure measurement, indoor gait analysis was performed along a $6 \mathrm{~m}$ walkway to determine the peak force exerted by the arms on adjustable, instrumented upper extremity assistive devices. Patients were tested with the type of device (crutch or cane) that they normally used. Values were expressed as a percentage of the patient's body weight (peak axial load). 


\section{Manual muscle testing/Ambulatory Motor Index}

Each subject underwent manual muscle testing at initial and follow-up tests by one of the authors (JY) using the standard 6 grade scale (Absent, Trace, Poor, Fair, Good, and Normal) (Kendall, 1971). In terms of the amount of strength needed to walk there is no significant difference between a grade of 'Trace' or 'Poor' since there is little difference in the amount of force generated between these muscle grades (Beasley, 1961). Also, from a functional standpoint, a grade of 'Good' is sufficient to meet the demands of level walking. Therefore, grades 'Trace' and 'Poor' as well as grades 'Good' and 'Normal' were combined into single groups. This enabled conversion of the 6 levels of manual muscle grades to a motor score based on a 4-point scale $(0=$ Absent, $1=$ Trace or Poor, $2=$ Fair, $3=$ Good or Normal).

During normal walking, hip and knee motion act synchronously to minimise energy expenditure. Foot and ankle play a less significant role (Inman, 1981; Waters, 1978). On this basis, quantification of the extent of lower extremity paralysis was achieved by adding the bilateral motor scores for hip flexion, hip abduction, hip extension, knee extension and knee flexion. The sum of these scores was expressed as a percentage of the maximum possible score ( 30 points). This value was defined as the Ambulatory Motor Index (AMI) (Waters, 1989).

\section{Statistical analysis}

Physiological and mechanical gait parameters were averaged over all collection periods for initial and follow-up testing. A multivariate analysis of variance (MANOVA) was performed to determine the overall difference $(\mathrm{p}<0.05)$ between initial and follow-up testing using the dependent measures: heart rate, velocity, oxygen consumption per heartbeat (oxygen pulse), oxygen cost per metre, peak axial load (PAL) on assistive devices, and the AMI. Individual univariate repeated measures analyses of variance (ANOVA) were then performed to determine significant $(p<0.05)$ differences between initial and follow-up testing for each of these variables considered separately.

The rate of oxygen consumption per minute and respiratory exchange ratio (RER) were excluded from analysis of variance. The former was deleted since previous reports have demonstrated that the rate of energy expenditure was not related to the AMI, type of assistive devices or orthoses (Waters, 1989); and the latter was deleted since ambulatory SCI patients walk at rates within their anaerobic thresholds (Waters, 1985, 1989). In addition, RER is a ratio of carbon monoxide expired to oxygen inspired, the values for which can be inconsistent depending upon hyperventilation and/or food consumed prior to testing (Astrand, 1977; McCardle, 1986). Since these variables were not controlled, RER data was only used to indicate variance above or below anaerobic threshold (greater than or less than 0.90 respectively).

Patients were further subdivided according to their AMI as described in a previous report (Waters, 1989). Group 1 included patients with an AMI score less than $40 \%$ of normal strength, group 2 referred to patients with an AMI score equal to or greater than $40 \%$ but less than $60 \%$ of normal strength, and group 3 included patients with an AMI score equal to or greater than $60 \%$ of normal strength. 
With oxygen pulse used as an measure of physiological efficiency an analysis of covariance was performed with initial heart rate measures as a covariate, to determine if improved walking efficiency was dependent upon lower extremity strength when controlling for initial conditioning level (i.e. heart rates).

\section{Results}

Initial and follow-up energy cost and gait parameters values for all subjects are listed in Table II. At follow-up testing 9 patients were community ambulators (cases 1, 2, 3, 4, 5, 6, 7, 8 and 9). Case 10 was a household ambulator whose primary mode of transport outside the home was the wheelchair.

\section{Initial vs follow-up testing: group differences}

MANOVA demonstrated a significant difference between initial and follow-up data in terms of heart rate, velocity, AMI, PAL, oxygen pulse and oxygen cost per metre $(\mathrm{p}<0.007)$.

Individual univariate analyses of variance for the group demonstrated increased velocity ( $59 \pm 23$ vs $40 \pm 19 \mathrm{~m} /$ minute; $\mathrm{p}<0.001)$, slower heart rates (115 \pm 19 vs $133 \pm 16$ beats/minute; $p<0.01$ ), decreased PAL on upper extremity assistive devices ( $18 \pm 31$ vs $26 \pm 28 \%$ body weight; $p<0.03$ ) and increased lower extremity strength (i.e. AMI) $(64 \pm 25$ vs $54 \pm 24 \%$ normal; p < 0.02$)$ at followup testing.

In addition, significant differences were found in oxygen pulse $(0.11 \pm 0.02 \mathrm{ml}$ $\mathrm{O}_{2} / \mathrm{kg}$-beat vs $0.14 \pm 0.03 \mathrm{ml} \mathrm{O} / \mathrm{kg}$-beat; $\left.\mathrm{p}<0.05\right)$ but there was no significant difference in the rate of oxygen consumption.

MANOVA applied to the data of the 9 community ambulators (case 10 excluded since he was the only subject limited to household ambulation and utilised a swingthrough gait) demonstrated a difference in initial and follow-up oxygen cost measures $(\mathrm{p}<0.029)$. Individual univariate ANOVA demonstrated oxygen cost per metre decreased significantly from initial to follow-up testing $(0.40 \pm 0.19$ vs $0 \cdot 26 \pm 0 \cdot 13 \mathrm{ml} \mathrm{O} / \mathrm{kg} \cdot \mathrm{m}, \mathrm{p}<0 \cdot 05)$.

\section{Initial vs follow-up testing: groups according to AMI}

When grouped according to their AMI at initial testing, group 1 (AMI $<40 \%$ of normal; cases 8 and 10) demonstrated an increased rate of oxygen consumption at lower heart rates between initial and follow-up testing, required greater than $22 \%$ body weight on assistive devices and walked slower than normal (able-bodied mean velocity of $80 \mathrm{~m} / \mathrm{minute}$ ) at follow-up testing. Group 2 (AMI $\geqslant 40 \%$ of normal but $<60 \%$ of normal; cases 1, 5, 6 and 9) had varied follow-up results. Two patients (cases 1 and 6 ) had a decreased rate of oxygen consumption, lowered heart rates, did not require upper extremity assistive devices and walked at normal velocities. Cases 5 and 9 had increased rate of oxygen consumption, 22 to $32 \%$ body weight on crutches and walked faster than initial testing but slower than normal.

Group 3 (AMI $\geqslant 60 \%$ of normal; cases 2, 3, 4, and 7) required no upper extremity assistive devices at follow-up testing. Three of the 4 patients' velocities 
Table II Summary of initial/follow-up testing of SCI patients

\begin{tabular}{|c|c|c|c|c|c|c|c|c|c|}
\hline Case & $\begin{array}{l}\text { Velocity } \\
(\mathrm{m} / \text { minute })\end{array}$ & $\begin{array}{c}\text { Heart rate } \\
\text { (beats/minute) }\end{array}$ & $\begin{array}{c}\mathrm{O}_{2} \text { rate } \\
(\mathrm{ml} / \mathrm{kg} \cdot \text { minute })\end{array}$ & $\begin{array}{c}\mathrm{O}_{2} \text { cost } \\
(\mathrm{ml} / \mathrm{kg} \mathrm{m})\end{array}$ & $\begin{array}{c}\mathrm{O}_{2} \text { pulse } \\
(\mathrm{ml} / \mathrm{kg} \cdot \text { beat })\end{array}$ & $\mathrm{RER}^{\star}$ & $\begin{array}{c}\text { PAL }^{\star \star} \\
(\% \text { body weight })\end{array}$ & 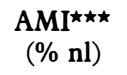 & Bracing \\
\hline $\begin{array}{l}1 \\
1 \dagger\end{array}$ & $\begin{array}{l}35 \\
45\end{array}$ & $\begin{array}{r}122 \\
92\end{array}$ & $\begin{array}{l}13 \cdot 3 \\
11 \cdot 0\end{array}$ & $\begin{array}{l}0 \cdot 38 \\
0 \cdot 25\end{array}$ & $\begin{array}{l}0 \cdot 116 \\
0 \cdot 119\end{array}$ & $\begin{array}{l}0.95 \\
0.81\end{array}$ & $\begin{array}{r}28 \\
0\end{array}$ & $\begin{array}{l}40 \\
67\end{array}$ & $\begin{array}{l}2 \text { AFOs } \\
\text { Same }\end{array}$ \\
\hline $\begin{array}{l}2 \\
2 \dagger\end{array}$ & $\begin{array}{l}68 \\
88\end{array}$ & $\begin{array}{l}131 \\
104\end{array}$ & $\begin{array}{l}14 \cdot 7 \\
12 \cdot 5\end{array}$ & $\begin{array}{l}0 \cdot 22 \\
0 \cdot 14\end{array}$ & $\begin{array}{l}0 \cdot 112 \\
0 \cdot 120\end{array}$ & $\begin{array}{l}0.95 \\
0.84\end{array}$ & $\begin{array}{l}5 \\
0\end{array}$ & $\begin{array}{l}100 \\
100\end{array}$ & $\begin{array}{l}2 \text { AFOs } \\
\text { None }\end{array}$ \\
\hline $\begin{array}{l}3 \\
3+\end{array}$ & $\begin{array}{l}46 \\
83\end{array}$ & $\begin{array}{l}116 \\
113\end{array}$ & $\begin{array}{l}14 \cdot 2 \\
12 \cdot 4\end{array}$ & $\begin{array}{l}0 \cdot 31 \\
0 \cdot 15\end{array}$ & $\begin{array}{l}0 \cdot 122 \\
0 \cdot 110\end{array}$ & $\begin{array}{l}0.86 \\
0.85\end{array}$ & $\begin{array}{r}15 \\
0\end{array}$ & $\begin{array}{l}80 \\
90\end{array}$ & $\begin{array}{l}2 \text { AFOs } \\
\text { None }\end{array}$ \\
\hline $\begin{array}{l}4 \\
4 \dagger\end{array}$ & $\begin{array}{l}40 \\
58\end{array}$ & $\begin{array}{l}107 \\
115\end{array}$ & $\begin{array}{l}14 \cdot 0 \\
12 \cdot 4\end{array}$ & $\begin{array}{l}0 \cdot 35 \\
0 \cdot 21\end{array}$ & $\begin{array}{l}0 \cdot 126 \\
0 \cdot 108\end{array}$ & $\begin{array}{l}0.97 \\
0.96\end{array}$ & $\begin{array}{l}2 \\
2\end{array}$ & $\begin{array}{l}60 \\
63\end{array}$ & $\begin{array}{l}1 \mathrm{KAFO} \\
\text { Same }\end{array}$ \\
\hline $\begin{array}{l}5 \\
5+\end{array}$ & $\begin{array}{l}17 \\
57\end{array}$ & $\begin{array}{l}131 \\
106\end{array}$ & $\begin{array}{l}12 \cdot 6 \\
15 \cdot 7\end{array}$ & $\begin{array}{l}0 \cdot 83 \\
0 \cdot 28\end{array}$ & $\begin{array}{l}0 \cdot 096 \\
0 \cdot 148\end{array}$ & $\begin{array}{l}0 \cdot 84 \\
0 \cdot 78\end{array}$ & $\begin{array}{l}30 \\
23\end{array}$ & $\begin{array}{l}47 \\
57\end{array}$ & $\begin{array}{l}\text { KAFO/AFO } \\
\text { Same }\end{array}$ \\
\hline $\begin{array}{l}6 \\
6+\end{array}$ & $\begin{array}{l}59 \\
80\end{array}$ & $\begin{array}{l}143 \\
119\end{array}$ & $\begin{array}{l}19 \cdot 3 \\
17 \cdot 2\end{array}$ & $\begin{array}{l}0 \cdot 33 \\
0 \cdot 21\end{array}$ & $\begin{array}{l}0 \cdot 149 \\
0 \cdot 145\end{array}$ & $\begin{array}{l}1.07 \\
0.86\end{array}$ & $\begin{array}{r}12 \\
0\end{array}$ & $\begin{array}{l}53 \\
77\end{array}$ & $\begin{array}{l}2 \text { AFOs } \\
\text { Same }\end{array}$ \\
\hline $\begin{array}{l}7 \\
7 \dagger\end{array}$ & $\begin{array}{l}58 \\
75\end{array}$ & $\begin{array}{r}126 \\
96\end{array}$ & $\begin{array}{l}8 \cdot 7 \\
9 \cdot 1\end{array}$ & $\begin{array}{l}0 \cdot 15 \\
0 \cdot 13\end{array}$ & $\begin{array}{l}0 \cdot 069 \\
0 \cdot 104\end{array}$ & $\begin{array}{c}0 \cdot 77 \\
-\end{array}$ & $\begin{array}{r}10 \\
0\end{array}$ & $\begin{array}{r}67 \\
100\end{array}$ & $\begin{array}{l}2 \text { AFOs } \\
\text { None }\end{array}$ \\
\hline $\begin{array}{l}8 \\
8+\end{array}$ & $\begin{array}{l}32 \\
43\end{array}$ & $\begin{array}{l}152 \\
150\end{array}$ & $\begin{array}{l}16 \cdot 4 \\
21 \cdot 8\end{array}$ & $\begin{array}{l}0.52 \\
0.51\end{array}$ & $\begin{array}{l}0 \cdot 108 \\
0 \cdot 146\end{array}$ & $\begin{array}{l}0 \cdot 84 \\
0 \cdot 77\end{array}$ & $\begin{array}{l}21 \\
22\end{array}$ & $\begin{array}{l}23 \\
53\end{array}$ & $\begin{array}{l}\text { KAFO/AFO } \\
2 \text { AFOs }\end{array}$ \\
\hline $\begin{array}{l}9 \\
9+\end{array}$ & $\begin{array}{l}40 \\
54\end{array}$ & $\begin{array}{l}156 \\
110\end{array}$ & $\begin{array}{l}19 \cdot 2 \\
23 \cdot 0\end{array}$ & $\begin{array}{l}0.48 \\
0.43\end{array}$ & $\begin{array}{l}0 \cdot 123 \\
0 \cdot 210\end{array}$ & $\begin{array}{l}0.92 \\
0.85\end{array}$ & $\begin{array}{l}35 \\
32\end{array}$ & $\begin{array}{l}40 \\
40\end{array}$ & $\begin{array}{l}2 \text { AFOs } \\
\text { Same }\end{array}$ \\
\hline $\begin{array}{l}10 \\
10 \dagger\end{array}$ & $\begin{array}{r}9 \\
12\end{array}$ & $\begin{array}{l}149 \\
148\end{array}$ & $\begin{array}{l}12 \cdot 9 \\
22 \cdot 1\end{array}$ & $\begin{array}{l}1 \cdot 39 \\
1.92\end{array}$ & $\begin{array}{l}0.086 \\
0.150\end{array}$ & $\begin{array}{l}1 \cdot 08 \\
0 \cdot 74\end{array}$ & $\begin{array}{l}53 \\
58\end{array}$ & $\begin{array}{l}27 \\
27\end{array}$ & $\begin{array}{l}2 \text { KAFOs } \\
\text { Same }\end{array}$ \\
\hline $\begin{array}{l}\text { Group } \\
\text { Group }\end{array}$ & $\begin{array}{l}\bar{x} \quad 40 \pm 19 \\
\bar{x} \dagger 59 \pm 23\end{array}$ & $\begin{array}{l}133 \pm 16 \\
115 \pm 19\end{array}$ & $\begin{array}{l}14 \cdot 5 \pm 3 \cdot 2 \\
15 \cdot 7 \pm 5 \cdot 1\end{array}$ & $\begin{array}{l}0 \cdot 40 \pm 0 \cdot 19^{\wedge} \\
0 \cdot 26 \pm 0 \cdot 13^{\wedge}\end{array}$ & $\begin{array}{l}0.11 \pm 0.02 \\
0.14 \pm 0.03\end{array}$ & $\begin{array}{l}0.94 \pm 0.09 \\
0.84 \pm 0.06\end{array}$ & $\begin{array}{l}26 \pm 28 \\
18 \pm 31\end{array}$ & $\begin{array}{l}54 \pm 24 \\
65 \pm 25\end{array}$ & \\
\hline
\end{tabular}

$t$ : follow-up data

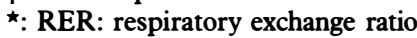

$\star \star$ PAL: peak axial load

$\star \star \star$ AMI: ambulatory motor index

^: calculated with case 10 excluded (see text) 
approximated normal (cases 2, 3 and 7), and only 1 (case 7) increased their rate of oxygen consumption which was still below normal at follow-up testing.

Controlling for initial heart rate measures, analysis of covariance demonstrated a significantly $(p<0.05)$ larger increase (mean of $0.060 \pm 0.020 \mathrm{ml} \mathrm{O} / 2 / \mathrm{kg} \cdot$ beat) in oxygen pulse between initial and follow-up testing in those patients (cases 5, 8, 9 and 10) who remained in group 1 or 2 (AMI less than $60 \%$ of normal) at followup testing when compared to patients who were in group 3 (AMI greater than $60 \%$ of normal) at follow-up testing. Those patients who were in group 3 at followup testing had a mean increase in oxygen pulse of only $0.002 \pm 0.019 \mathrm{ml}$ $\mathrm{O}_{2} / \mathrm{kg} \cdot$ beat.

\section{Discussion}

All patients made significant improvements in ambulation capacity from discharge to follow-up testing. Improvements were demonstrated in both strength and conditioning gains. These gains characterise the interrelationship between lower extremity strength, arm work and improved conditioning.

Previous reports have demonstrated the per cent increase in oxygen consumption compared to normals walking at comparable velocities was dependent upon the lower extremity strength as measured by the AMI (Waters, 1989). As the AMI increased, the upper extremity load on assistive devices decreased and oxygen consumption when compared to normals walking at the same speed also decreased. With decreased strength in the lower extremities (decrease in the AMI), the requirement for upper extremity assistance was increased and subsequently, oxygen consumption increased. These relationships were evident in the follow-up data.

Those patients who had relatively weaker lower extremities (AMI less than $60 \%$ of normal; group 1 or 2; cases 5, 8, 9 and 10) at initial and follow-up testing demonstrated a larger increase in walking efficiency (oxygen pulse) between tests when compared to those patients with stronger lower extremities (greater than $60 \%$ of normal; group 3; cases 1, 2, 3, 4, 6 and 7) at follow-up testing. This was very significant when considering initial conditioning levels (heart rates) were controlled and sample size was small $(n=10)$.

The former group's lower extremity weakness necessitated greater than $21 \%$ of their body weight on crutches at both initial and follow-up testing while patients in the latter group (greater than $60 \%$ of normal) required only 0 to. $2 \%$ of body weight on assistive devices at follow-up testing. This increased arm work corresponded to initially higher heart rates (averaging 147 beats/minute) for the weaker group compared to the group with greater than $60 \%$ of normal lower extremity strength which had initial heart rates of 124 beats/minute.

For conditioning effects to occur, chronic stress must be placed on the cardiovascular system (McCardle, 1986). We conclude that those patients with relatively weaker lower extremities at follow-up required greater assistance on upper extremity crutches for longer periods, therefore demonstrated greater conditioning effects.

In order to accommodate for gait disabilities, patients will walk at self-selected velocities where oxygen demands meet aerobic capacity. If oxygen demands are below anaerobic threshold, activity can continue indefinitely (McCardle, 1986). At follow-up testing most patients were below anaerobic thresholds (RER less than 
0.90 ) and had increased ambulation speed. Only 4 out of 10 patients, however, were walking at speeds approximating normal. From a functional standpoint, improved speeds enhance performance, yet 6 of these patients continued to require a longer period of time to ambulate community distances.

Although motivation and environment have varying effects on the amount and consistency of ambulation, all 10 patients made significant improvements between initial and follow-up testing. We conclude by saying that those patients with relatively weaker lower extremities will have larger conditioning effects if ambulation practices are continued, due to increased stress on the cardiovascular system, and the demands of walking can remain considerable as long as 1 year postdischarge in the SCI population.

\section{References}

Astrand PO, Rodahl K 1977 Textbook of Work Physiology, 2nd edn. McGraw-Hill, New York.

BEASLEY WC 1961 Quantitative muscle testing: principles and clinical application to research and clinical services. Archives of Physical Medicine and Rehabilitation 42:398-425.

Chantraine A, Crielaard JM, Onkelinx A, Pirnay F 1984 Energy expenditure of ambulation in paraplegics: Effects of long term use of bracing. Paraplegia 22:172-181.

Clinkingbeard JR, JeROME WG, HoEhn D 1964 Energy cost of ambulation in the traumatic paraplegic. American Fournal of Physical Medicine 13:157-165.

GORDON EE, VANDERWALDE H 1956 Energy requirements in paraplegic ambulation. Archives of Physical Medicine and Rehabilitation 37:276-285.

HuANG CR, KuhlemeIER KV, MOORE NB, FINE PR 1979 Energy cost of ambulation in paraplegic patients using Craig-Scott braces. Archives of Physical Medicine and Rehabilitation 60:595-600.

InMAN VT, RaLston HJ, TodD F 1981 Human Walking. Waverly Press, Baltimore.

Kendall HO, Kendall FP, Wadsworth GE 1971 Muscles Testing and Function. Waverly Press, Baltimore.

McCardle CW, Katch FI, Victor KL 1986 Exercise Physiology, 2nd edn. Lea and Febiger, Philadelphia.

Merkel K, Miller N, MerritT J 1985 Energy expenditure in patients with low-, mid-, or highthoracic paraplegia using Scott-Craig knee-ankle-foot orthoses. Mayo Clinic Proceedings 60:165168 .

WATERS RL, BARNES G, HUSSERL T, SILVER L, LISS 1988 Comparable energy expenditure following arthrodesis of the hip and ankle. Fournal of Bone and Foint Surgery 70:1032-1037.

Waters RL, Hislop HJ, PerRy J, ANTONelli D: Energetics 1978 Application to the study and management of locomotor disabilities. Orthopaedic Clinics of North America 9:351-377.

WATERS RL, LUNSFORD B 1985 Energy cost of paraplegic locomotion. Fournal of Bone and Foint Surgery 67:1245-1250.

WATERS RL, YAKURA JS, ADKINS R, BARNES G 1989 Determinants of gait performance following spinal cord injury. Archives of Physical Medicine and Rehabilitation 70:811-818 